University of South Florida

DIGITAL COMMONS

Digital Commons @ University of

@ UNIVERSITY OF SOUTH FLORIDA

South Florida

The Inside, Outside, and Upside Downs of

Children's Literature: From Poets and Pop-ups

to Princesses and Porridge

$1-1-2016$

\title{
Chapter 01: Why Are You Reading Kids' Books?
}

Jenifer Jasinski Schneider

University of South Florida, jschneid@usf.edu

Follow this and additional works at: https://digitalcommons.usf.edu/childrens_lit_textbook

Part of the Education Commons

\section{Recommended Citation}

Schneider, Jenifer Jasinski, (2016). Why Are You Reading Kids' Books? In The Inside, Outside, and Upside Downs of Children's Literature: From Poets and Pop-ups to Princesses and Porridge (p. 1-8).

http://dx.doi.org/10.5038/9780977674411.ch1

This Book Chapter is brought to you for free and open access by the Teaching and Learning at Digital Commons @ University of South Florida. It has been accepted for inclusion in The Inside, Outside, and Upside Downs of Children's Literature: From Poets and Pop-ups to Princesses and Porridge by an authorized administrator of Digital Commons@ @niversity of South Florida. For more information, please contact digitalcommons@usf.edu. 


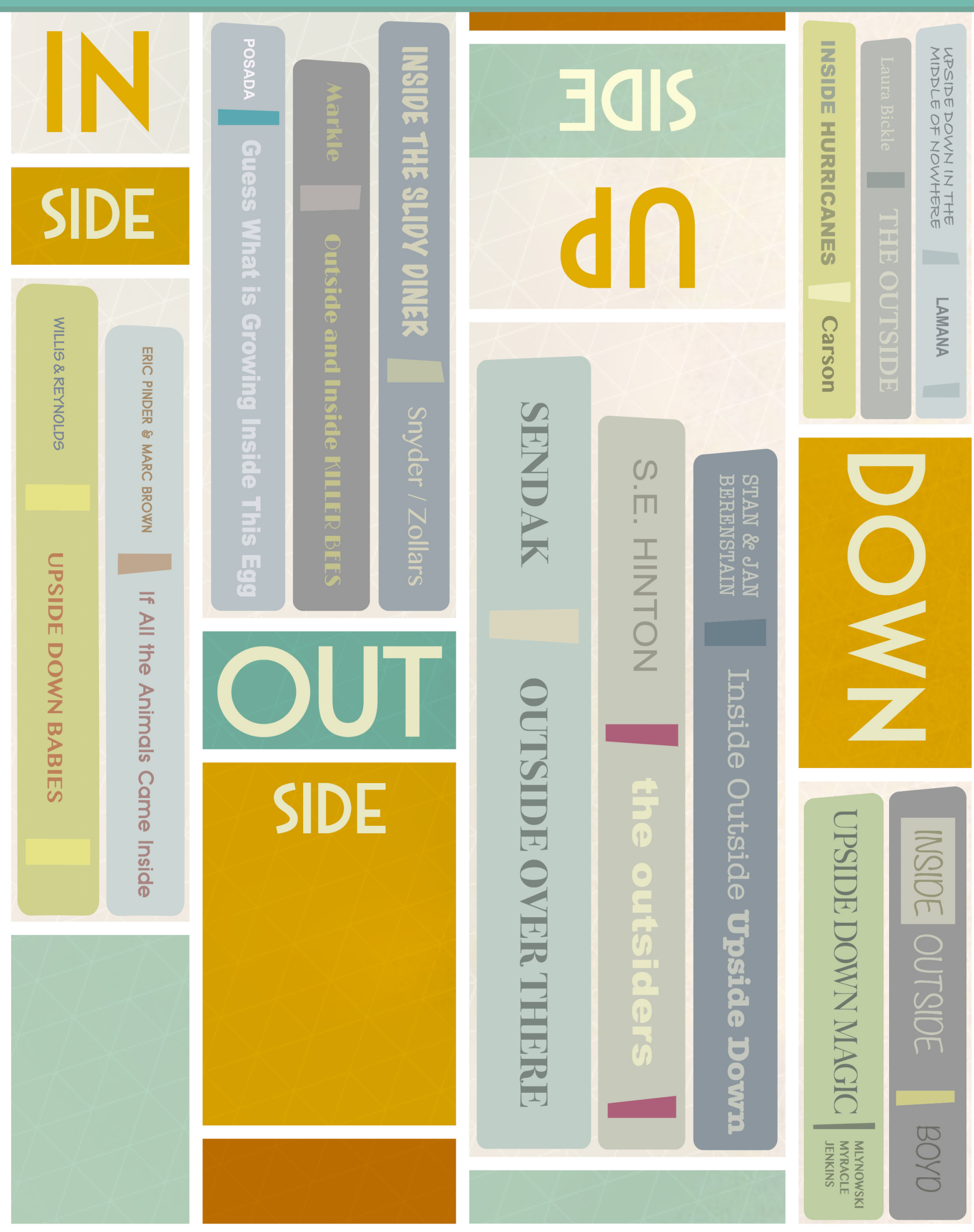

\section{THE INSIDE, OUTSIDE, AND UPSIDE DOWIS From Poets and Pop-ups to OF CHILDREN'S LITERATURE Princesses and Porridge}




\section{The Inside, Outside, and Upside Downs of Children's Literature: From Poets and Pop-ups to Princesses and Porridge}

Jenifer Jasinski Schneider, Ph.D. 
Copyright

Published by The University of South Florida Library, 4202 E. Fowler Avenue, Tampa, FL 33620.

Copyright (C2016 by Jenifer Jasinski Schneider. All rights reserved.

\section{(c) $(1) \odot$}

This work is licensed under a Creative Commons Attribution-NonCommercial-NoDerivatives 4.0 International License.

Author and Editor in Chief: Jenifer Jasinski Schneider

Editorial Director: Monica Metz-Wiseman

Media Project Manager and Producer: Christine Brown

Video Producers and Editors: Jared Brown, Jason Su, Ian Crenshaw, Jessica Brennen,

Diana Trueman, Jeremy Willis

Art Director: Stephanie Rivera

Illustrators and Multimedia Designers: William Tillis and Elise Michal

Copyright Coordinator: LeEtta M. Schmidt

Open-Access Editor: Jason Boczar

Editorial Manager: Carol Ann Borchert

Editorial Project Manager: Chelsea Johnston

Cover image book credits:

Upside Down Babies by Jeanne Willis and Adrian Reynolds (C)2013 Andersen Press; If All the Animals

Came Inside by Eric Pinder and Marc Tolon Brown (C)2012 Little, Brown and Company; Guess What Is Growing Inside This Egg by Mia Posada (C2007 Millbrook Press; Outside and Inside Killer Bees by Sandra Markle (C)2004 Walker \& Co.; Inside the Slidy Diner by Laurel Snyder and Jaime Zollars (C)2008 Tricycle Press; Outside Over There by Maurice Sendak (C)1989 HarperCollins; The Outsiders by S.E. Hinton, original cover art by Robert Hunt (C1967 Viking Press. Mass Market edition (C1997 Speak; Inside Outside Upside Down by Stan and Jan Berenstain (C1968 Random House; Upside Down Magic by Sarah Mlynowski, Lauren Myracle, and Emily Jenkins (C)2015 Scholastic Press; Inside Outside by Lizi Boyd (C)2013 Chronicle Books; Inside Hurricanes by Mary Kay Carson (C)2010 Sterling; The Outside by Lauren Bickle (C)2013 Houghton Mifflin Harcourt; Upside Down in the Middle of Nowhere by Julie T.

Lamana (C)2014 Chronicle Books.

Library of Congress Cataloging-in-Publication Data

Schneider, Jenifer Jasinski, 1968-

The Inside, Outside, and Upside Downs of Children's Literature: From Poets and Pop-ups to Princesses and Porridge / Jenifer Jasinski Schneider.

ISBN- 978-0-9776744-1-1 eBook

ISBN- 978-0-9776744-2-8 print

The Internet addresses listed in the text were accurate at the time of publication. 


\section{TEXTUAL TENDENCIES AND OPEN AND CLOSE READINGS}

\section{SECTION 1}




\section{CHAPTER \\ 01 \\ WHY ARE YOU READING \\ KIDS' BOOKS? \\ ANINTRODUCTION}

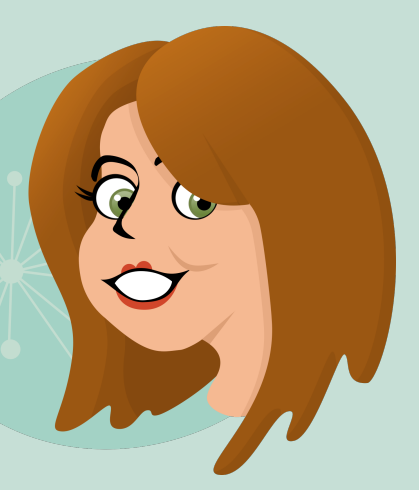

Children's literature is the foundation for youth's literacy development. Children and young adults need to engage in literary and aesthetic acts because they are essential for human growth. In other words, kids must read books in order to learn and grow. You are an adult. What are you doing here?

Why are you reading kids' books? I'll take a few guesses.

- You are interested in children's literature because you have fond memories of books from your youth (Figure 1.1). You enjoyed these books as a child and you would like to revisit them as an adult.

Welcome! I will review some old favorites and introduce you to new ones as well.

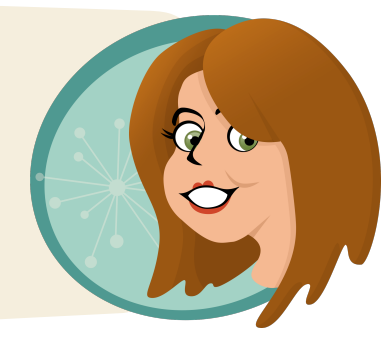

- You are a writer or artist (or both) and you want to create books for children; therefore, you want to know more about the field. Or, you might have a strong literary background in other areas of literature and you want to build complementary knowledge in children's literature (Figure 1.2).

Great. You are in the right place.

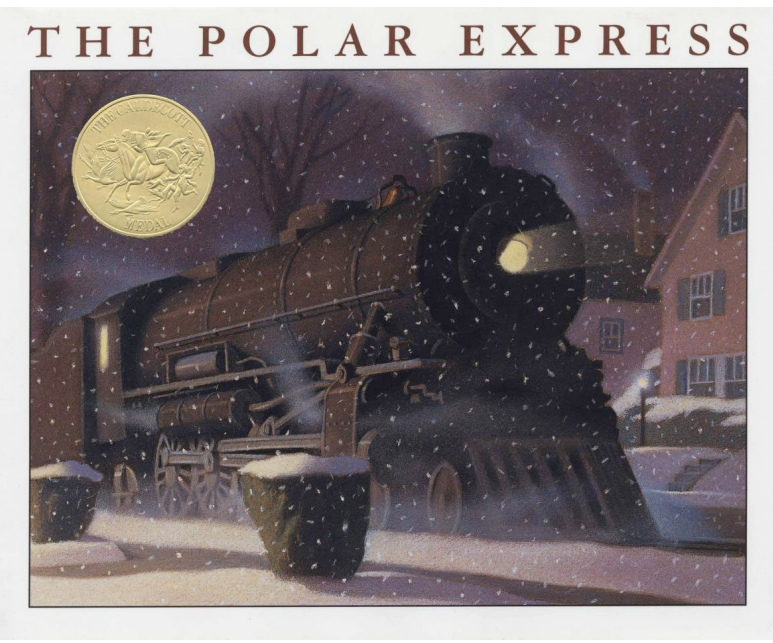

Figure 1.1

A classic image from The Polar Express, by Chris Van Allsburg, 1983, New York, NY: Scholastic. Copyright 1983 by Chris Van Allsburg.

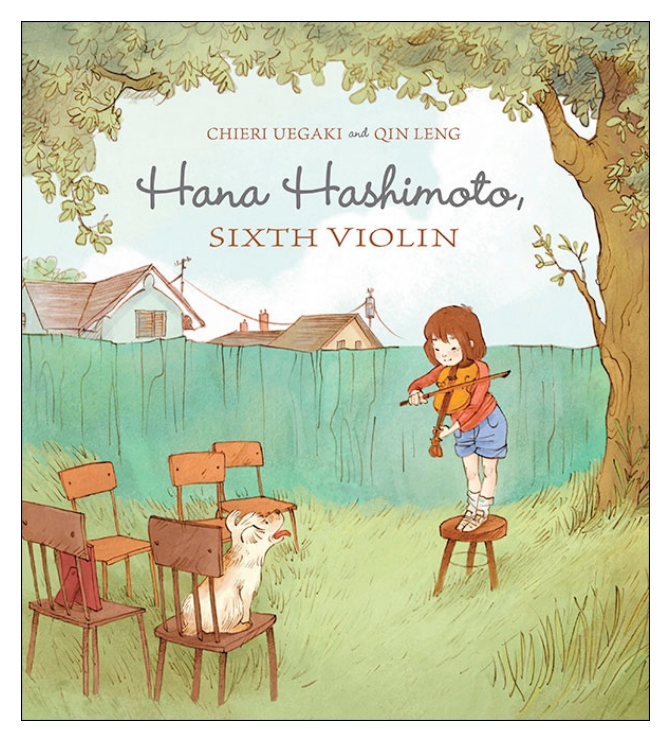

Figure 1.2

Explore newer books. Hana Hashimoto, Sixth Violin by Chieri Uegaki and illustrated by Qin Leng, 2014, Toronto, CA: Kids Can Press. Copyright 2014 by Qin Leng. 
- You have (or will have) children in your life and you want to know how to select books for them. Alternatively, you might also want to know which books are best for reading aloud (Figure 1.3). You probably want to know when you should stop reading aloud to kids or when kids are too old for books with pictures. (Short answer: Never!)

I will provide a thorough response to these questions and address many more.

- You have children in the center of your career path (nurse, doctor, dentist, social worker, psychologist, lawyer, minister), and you need to know what children read, why children read, and how children's books work in connection with children's social, emotional, and physical developmental progression (Figure 1.4).

We definitely will explore these topics.

- You have children in the margins of your career path (children in waiting rooms, employees with children, working with children's charities, designing, building, or decorating schools, libraries, hospitals or offices, for example), and you want to know how or where children read (Figure 1.5).

Yes, I will discuss the faces, places, and spaces of children's literature.

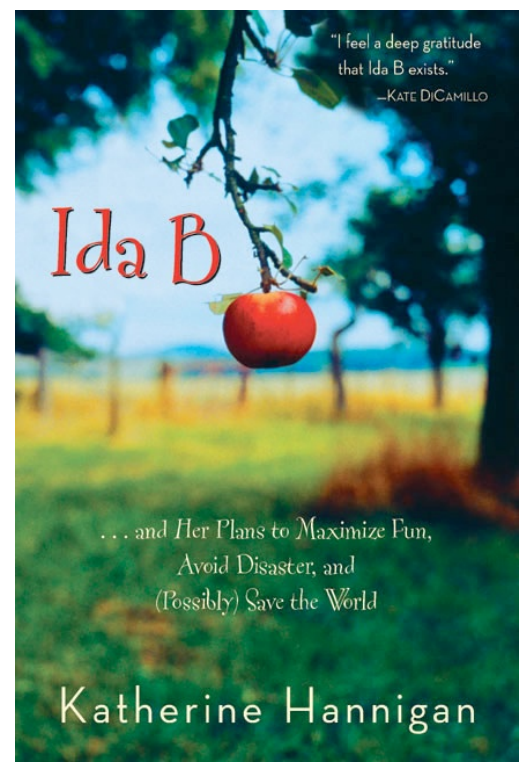

Figure 1.3

A wonderful book, perfect for reading aloud. Ida B... and Her Plans to Maximize Fun, Avoid Disaster, and Save the World by Katherine Hannigan and cover illustration by Dana Tezarr, 2004, New York, NY: Greenwillow/HarperCollins. Cover art copyright 2004 by Greenwillow/HarperCollins.

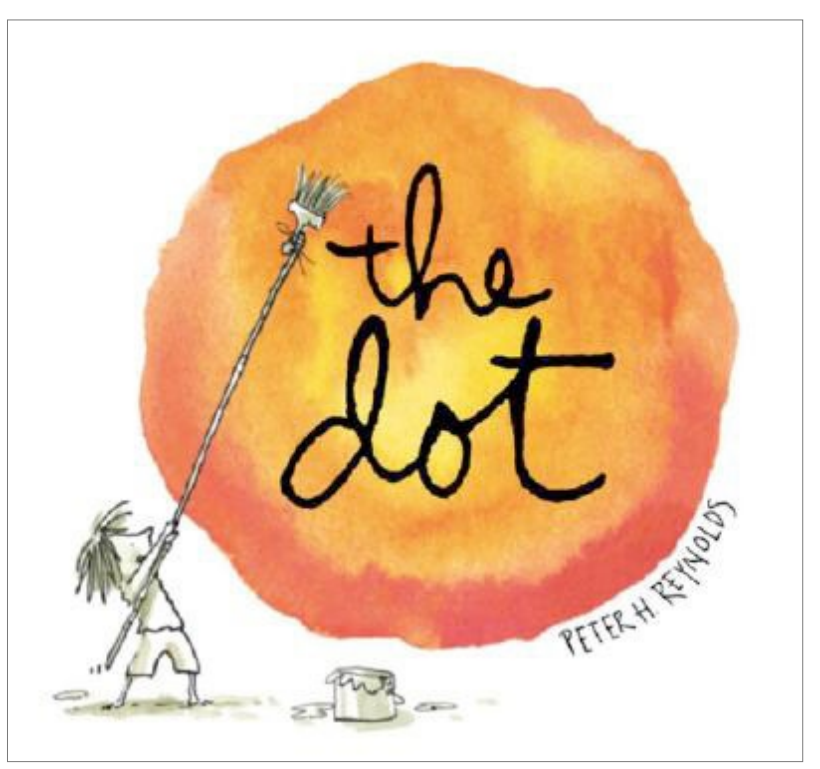

Figure 1.4

Peter H. Reynolds' The Dot demonstrates how small moments can make significant changes to a child's life. The Dot by Peter H. Reynolds, 2003, Somerville, MA: Candlewick Press. Copyright 2003 by Peter H. Reynolds.

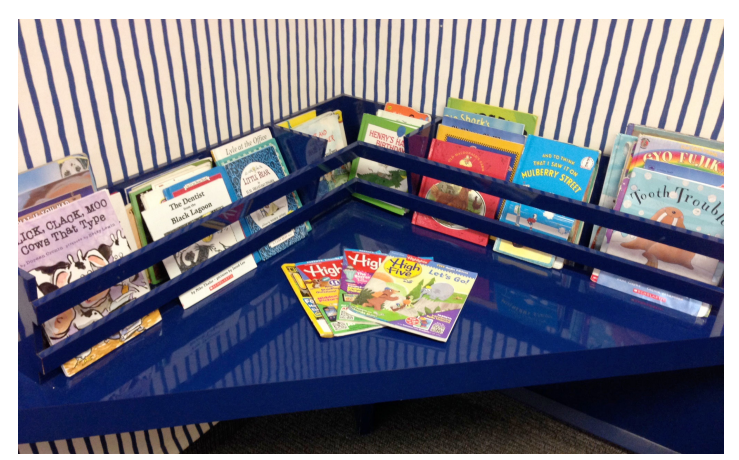

Figure 1.5

The waiting room at the office of Gerald Copeland, D.D.S., Tampa, FL. Photo copyright 2015 by Jenifer Jasinski Schneider. 
- Or perhaps children are the beneficiaries of your career path. You are a musician, graphic designer, computer programmer, lawyer or advertiser, for example, and you are interested in the entertainment industry or business aspects of children's literature, games, apps, and movies (Figure 1.6).

This book has something for you too.

- You don't have children in your personal life or crossing your professional career path, but you want to know the ways in which children's literature socializes youth, politicizes identity, represents history, and becomes art (Figure 1.7).

Yes, we will go there.

- You are taking a class in children's literature because you think it will be an easy A. After all, children's literature is written for children and youth; therefore, children's books must be easy to comprehend with simplistic plots and lots of pictures (Figure 1.8).

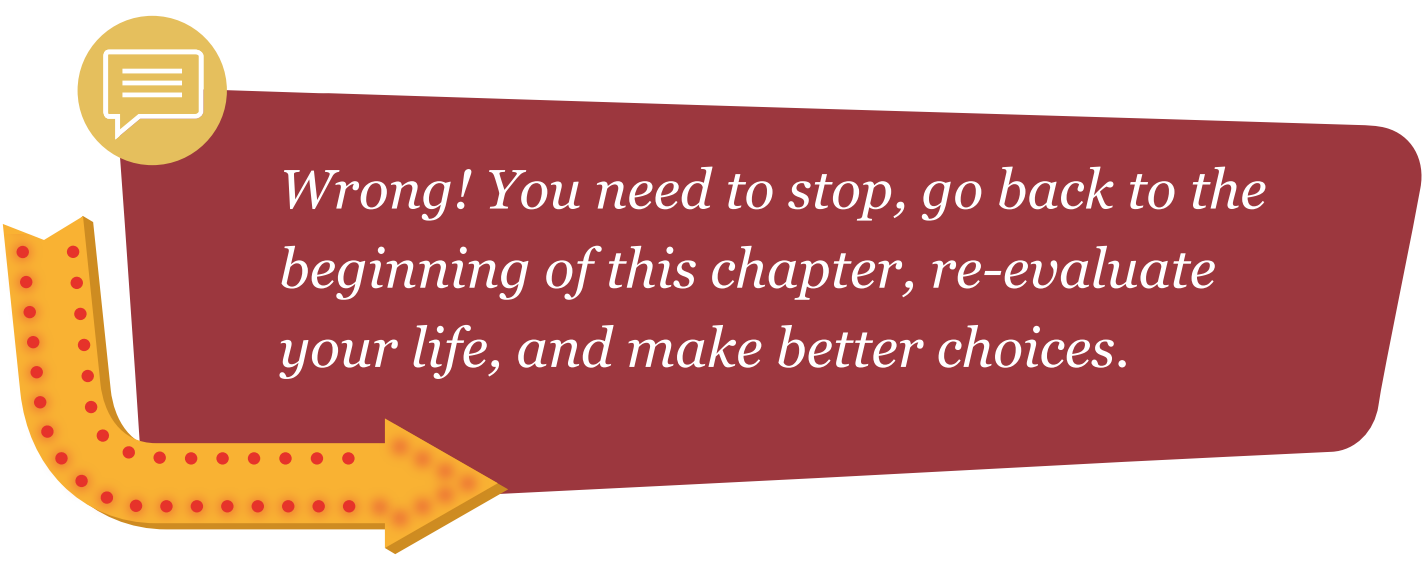

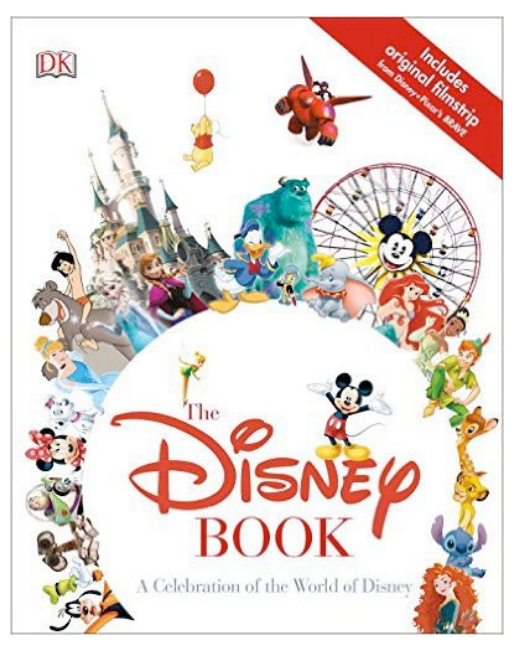

Figure 1.6

The Walt Disney Company is one example of an enterprise that has impacted the production of children's books. For an overview of the Disney industry, Jim Fanning's The Disney Book provides visual highlights and an historical synopsis. The Disney Book, by Jim Fanning, 2015, New York, NY: DK. Cover art copyright 2015 by Disney.

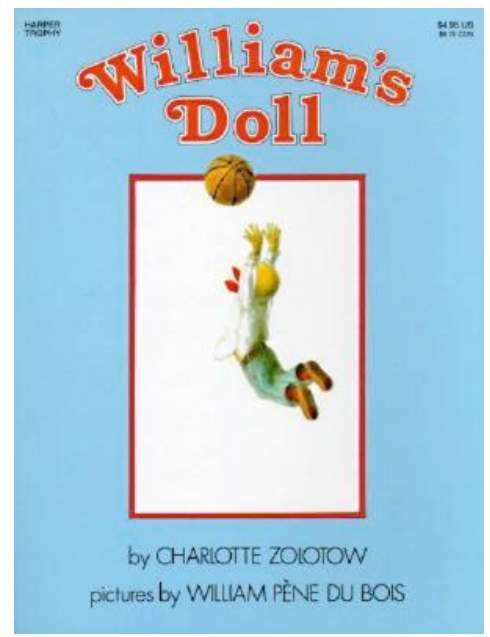

Figure 1.7

Explore what can happen when boys love dolls. William's Doll by Charlotte Zolotow and illustrated by William Pene du Bois, 1972, New York, NY: Harper \& Row. Copyright 1972 by William Pene du Bois.

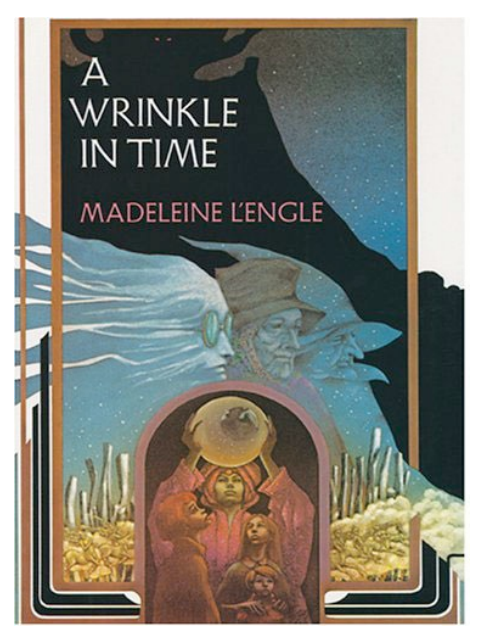

Figure 1.8

If you think children's books are "easy," think again. One example of young adult fiction with complex plots and characters is A Wrinkle In Time by Madeleine L'Engle, 1962, New York, NY: Farrar, Straus, and Giroux. Cover illustration copyright 1979 by Leo and Diane Dillon. 
Children's literature is written for children and youth, but the analysis of children's literature requires careful attention to text as well insightful interpretation of the ways in which authors and illustrators present the human condition, the physical world, imaginative experiences, and global forces. Children's literature is also a \$4-billion-a-year industry that impacts social practices, politics, financial markets, schools, literacy rates, history, and art. Whatever the reason for your interest, children's literature is a big deal.

According to IBISWorld (2015), the children's literature industry "designs, edits and markets books for children aged 17 and under, including coloring and picture books. It does include e-books, but excludes online-only publishers and authors, as well as textbook publishing." The Children's Book Publishing market research report indicates $\$ 4$ billion in annual revenue. (http://www.ibisworld.com/industry/childrens-book-publishing.html)

In addition, the children's market is driving growth across the publishing industry with a trend for increasing sales (Jarrod, 2015).

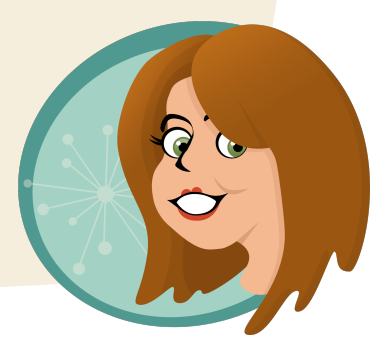

Video 1.1 Why are you reading kids' books? (An Introduction) http://www.kaltura.com/tiny/yn1jr

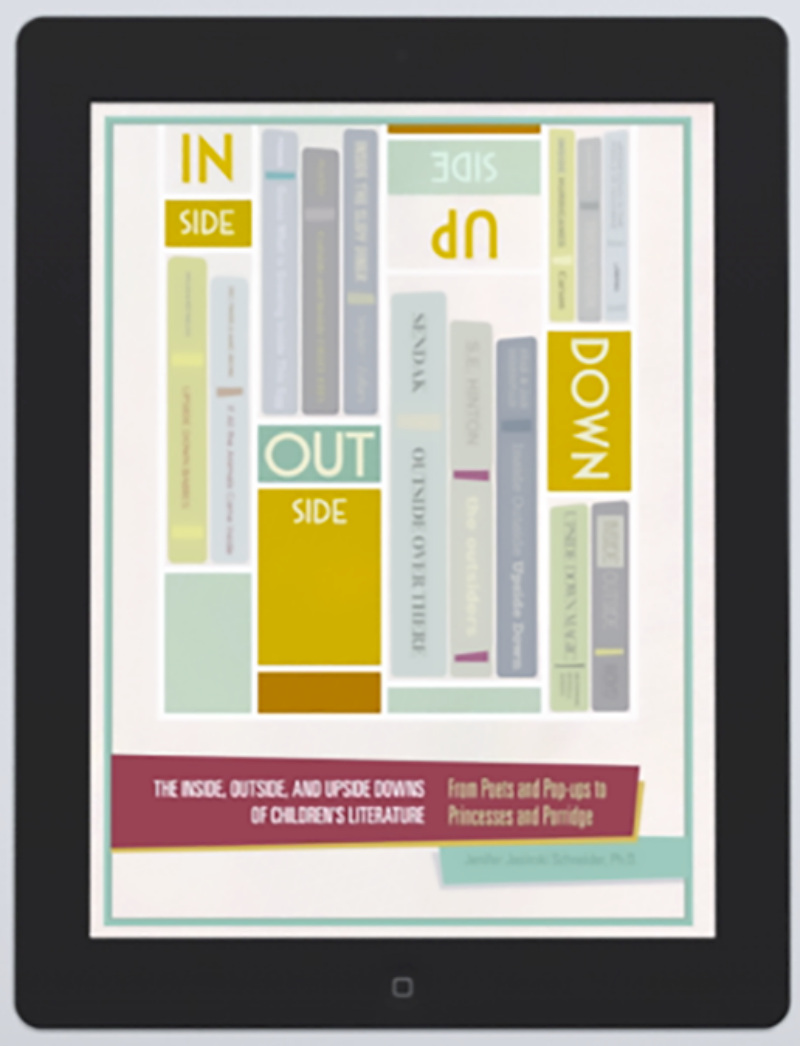

Overview of The Inside, Outside, and Upside Downs of Children's Literature: From Poets and Pop-ups to Princesses and Porridge. Copyright 2015 Jenifer Jasinski Schneider. 


\section{Purpose}

The purpose of this book is to introduce you to the field of children's literature. My goals for you are as follows: develop an appreciation of children's literature as a literary art form, learn how children's books and text structures work to create meaning, and to acquire strategies for critically evaluating books written for children and youth. In addition, you will examine societal trends and cultural issues in connection to particular texts and across the field of children's literature.

\section{Different Uses for Different Audiences}

By creating an e-textbook, I have integrated relevant digital resources and provided an interactive space for exploring the content that meets the needs of many audiences.

\section{Audiences with Professional Interests in Connection to Children}

This book is relevant for professionals who work with children in the fields of medicine, health, sports, entertainment, arts, journalism, politics, or business, etc. Knowing what children read, how children's books work, and the value of children's literature in society is relevant information for your career (Figure 1.9). For example, you need to know what children read so you can fill your waiting rooms with appropriate books of interest. You need to know how children's books work so you can select the right books for the right children. And you need to understand the importance of children's literacy development so you will be motivated to support literacy in all of your workspaces.

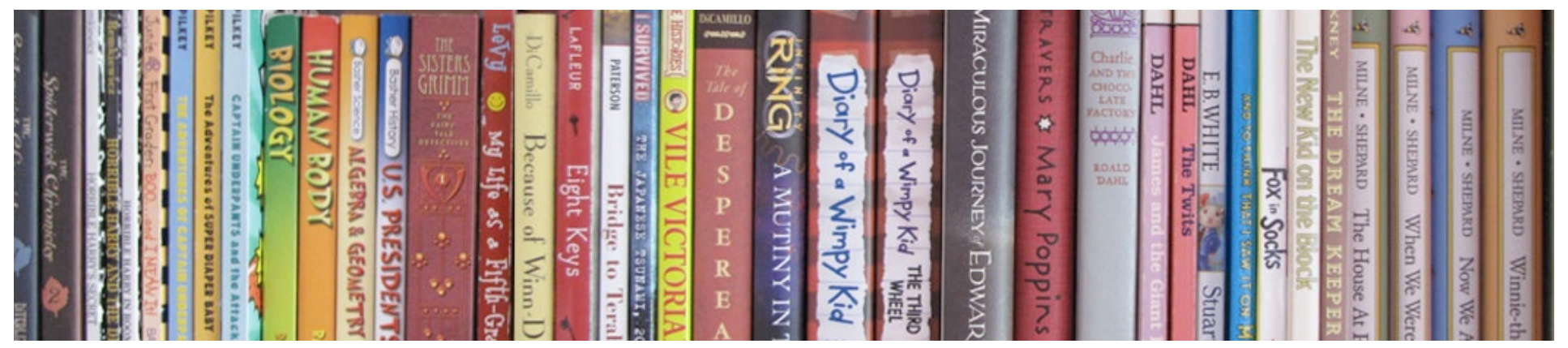

Figure 1.9

With thousands of children's and young adult books published each year, it's important to know how to select books. Copyright 2015 by Jenifer Jasinski Schneider. 


\section{Audiences with Professional Interests in Library Science, English, or Education}

This book is relevant for literacy specialists, librarians, and literary critics at the undergraduate and graduate levels. Given my broad focus on enjoyment, critical judgment, and appreciation, those of you in the fields of library, education, and English can use this book to advance your knowledge of the history of children's literature, stay updated with current trends, and pursue thematic study in your areas of interest. The book could be used in study groups, professional learning communities, university courses, and professional development seminars at the local, national, and international levels.

\section{Audiences with Personal Interests in Children's Literature}

Many children's literature texts are written for K-12 educators or librarians, but you won't find lesson plans in this book. Instead, for those of you with a personal interest in children's literature, I have written a topical textbook in which you can explore broad issues such as the banning of books, the writing and marketing of series books, and diversity and cultural portrayals.

\section{Audiences in the US and Around the Globe}

This book is relevant to US audiences as most of the examples are drawn from children's literature published in English. However, the book also includes specific references to international children's literature and guides readers to explore databases and collections of diverse examples (e.g., International Children's Digital Library http://en.childrenslibrary.org or the USF Children's and Young Adult Literature Special Collection http://www.lib.usf.edu/specialcollections/childrens-young-adult-literature/). Therefore, this book also crosses political, cultural, and social borders. 


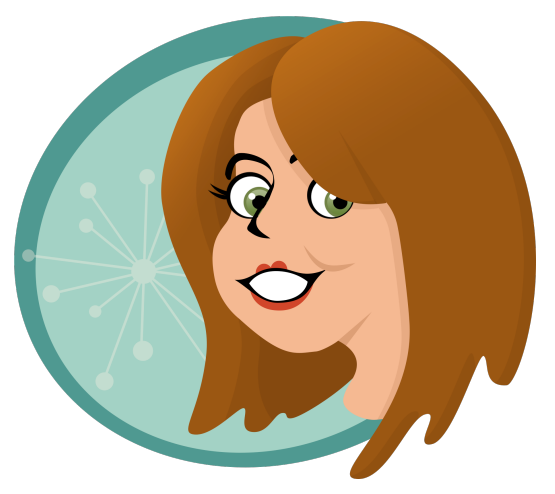

\section{Key Features}

The Inside, Outside, and Upside Downs of Children's Literature: From Poets and Pop-ups to Princesses and Porridge integrates relevant digital resources and provides an interactive space for learning that is affordable and accessible and meets the needs of multimodal readers and learners.

\section{GRAPHICS}

Each chapter includes graphics to help you navigate the book and to provide quick visual summaries or questions to guide your thinking.

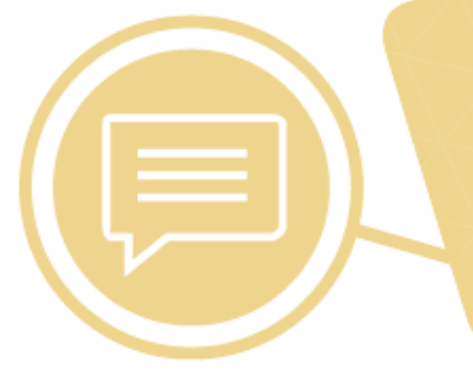

\section{COMMENT BUBBLES}

Throughout the book, comment bubbles provide a space for me to post additional information or add behind-the-scenes commentary. In other words, comment bubbles are the spaces where I let you know what I really think.

\section{PHOTOGRAPHS/VIDEO}

Visual images of children's books are important features of the book. I included photographs of cover art and illustrations. I also embedded video content from Youtube, TED talks, and I also created my own-with a little help from my friends.
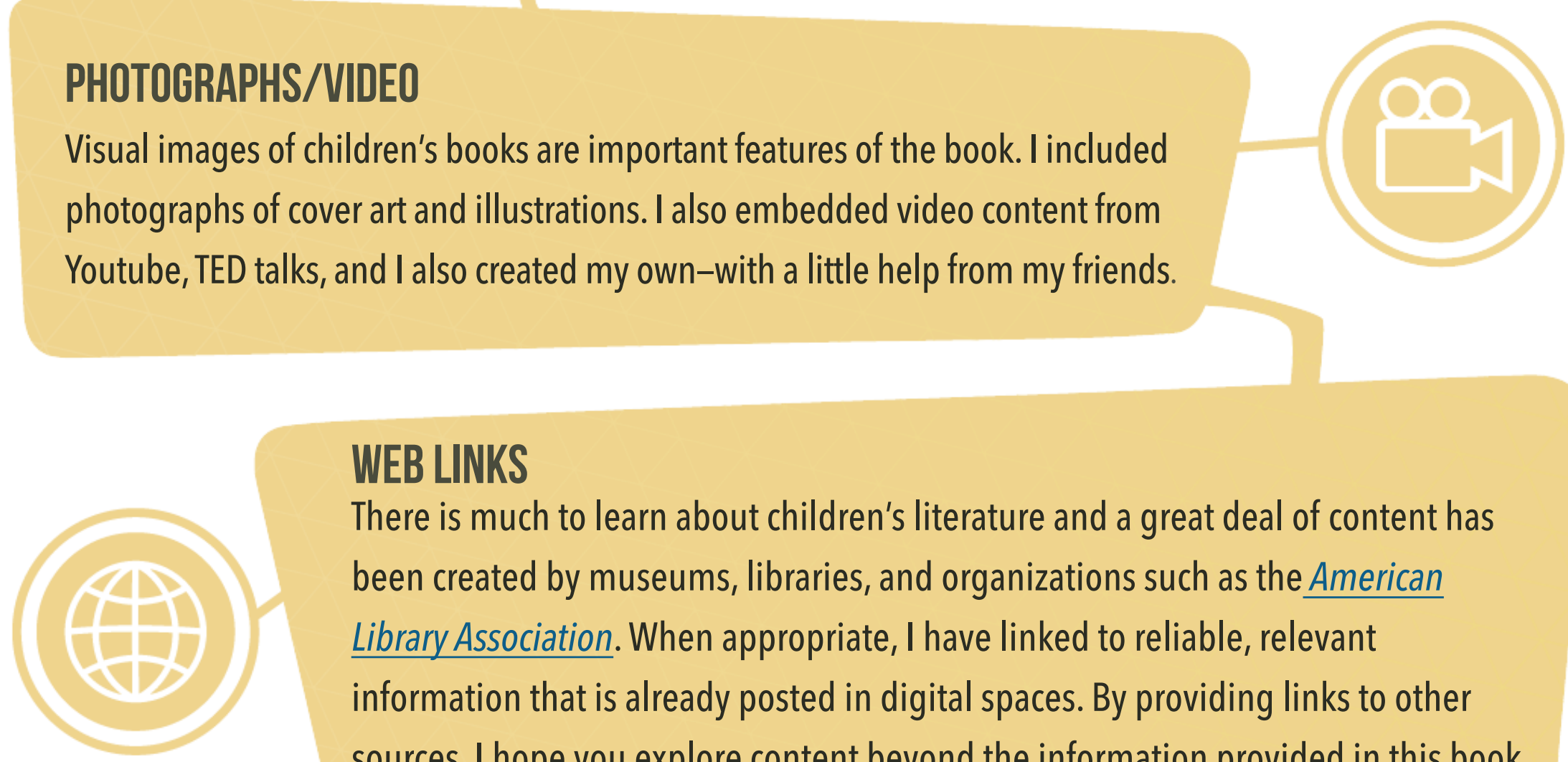

\section{WEB LINKS}

There is much to learn about children's literature and a great deal of content has been created by museums, libraries, and organizations such as the American Library Association. When appropriate, I have linked to reliable, relevant information that is already posted in digital spaces. By providing links to other sources, I hope you explore content beyond the information provided in this book. 


\section{About the Author}

I spent my life as an avid reader and fan of children's literature. I also spent my career reading and studying children's literature as an elementary teacher and then as a professor of literacy studies at the University of South Florida.

I am obsessed with arts-based approaches to literacy education including the ways in which children's literature, process drama, and technological tools support symbolic development

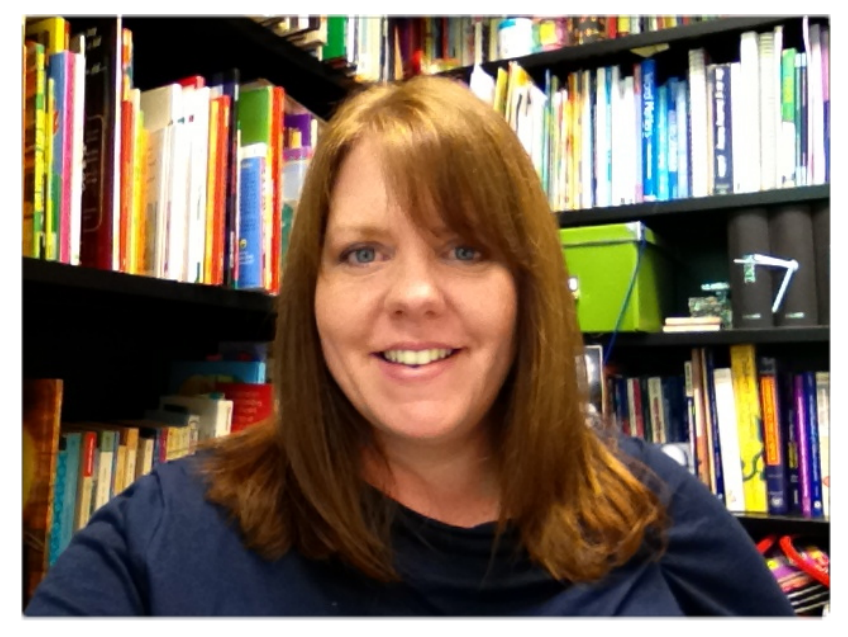
and meaning-making strategies. I appreciate the literariness of children's literature and derive aesthetic pleasure from the images (if present). I also greatly respect the roles of librarians as mediators of collections and keepers of the texts.

I believe (actually, I know) children's literature is relevant to adults because children's literature includes some of the highest quality writing, art, story, and informational content available. Children's literature is worthy of reading, discussion, study, and critique.

I have high expectations for the quality of children's literature, but with that said, I do not care what children and young adults read as long as they read. I believe it is the role of adults (parents, teachers, and other mentors) to expose reluctant readers to outstanding exemplars and to encourage broader reading and lifelong habits because, let's face it, passionate readers will find quality. It is the struggling readers who need help finding motivating and interesting texts that are relevant to their lives. Struggling readers do not need competitions, leveled books, or colored dots to encourage their reading. They need to be guided by role models who can help them find the right books (Figure 1.10).

I do not care what adults read. I am a passionate defender of the right to read. I believe banning books is un-American, and "scholars," critics, or other individuals who defend free speech and the freedom to read should not shame adults who read children's literature or tell youth what they should or should not read.

Children's literature is important, the stories are relevant, and the information will change the way you see the world.

\section{WHAT WOULD YOU RATHER READ?}

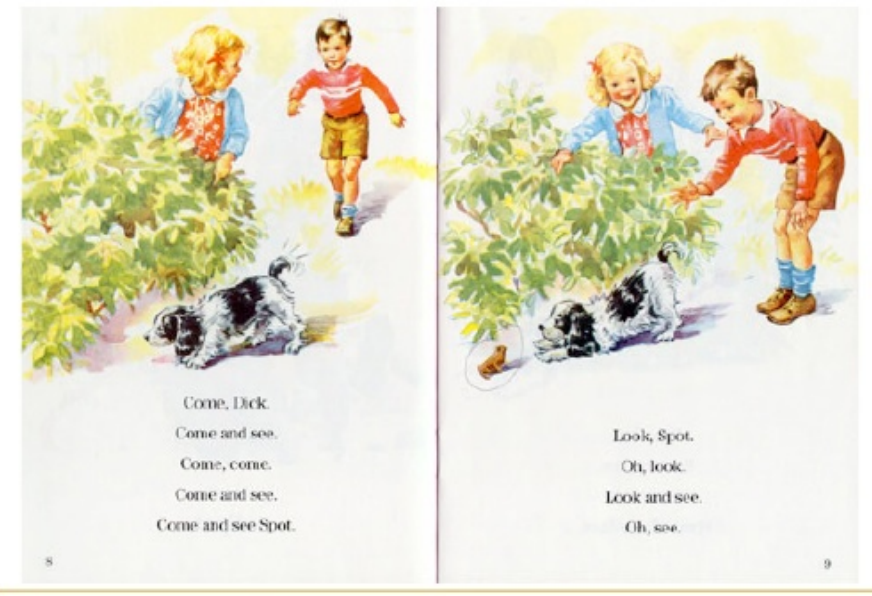

LEONARDO TRIED TERY HARD

TO BR SCARY.

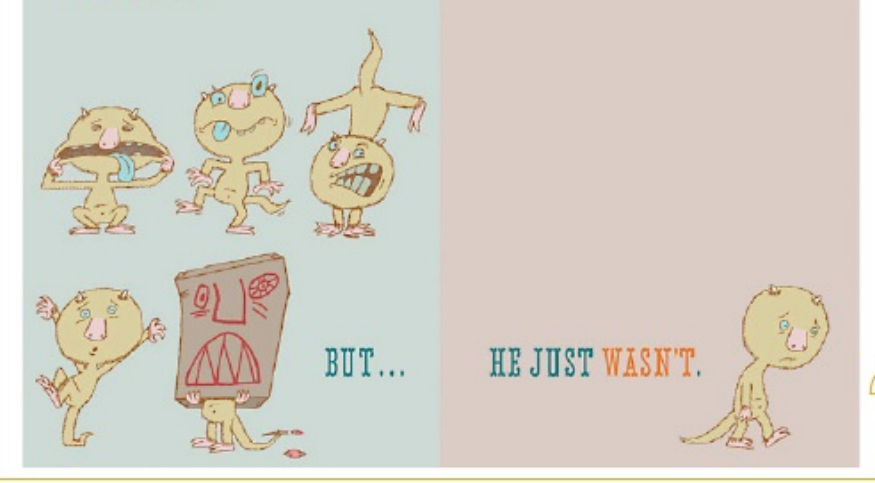

Figure 1.10

Which book would you rather read?

Dick and Jane by William S. Gray and illustrated by Zerna Sharp, 2004, New York, NY: Grosset \& Dunlap. Illustration copyright 2004 by Zerna Sharp. Leonardo the Terrible Monster by Mo Willems, 2005, New York, NY: Hyperion. Illustration copyright 2005 by Mo Willems. 